\title{
The Explicit Instruction of Reading Strategies: Directed Reading Thinking Activity vs. Guided Reading Strategies
}

\author{
Mohammad Mehdi Yazdani \\ ELT Department, Faculty of Persian Literature and Foreign Languages, Roudehen Branch, Islamic Azad University, Roudehen, Iran \\ E-mail: mmehdiyazdani90@yahoo.com \\ Mojtaba Mohammadi (Corresponding Author) \\ ELT Department, Faculty of Persian Literature and Foreign Languages, Roudehen Branch, Islamic Azad University, Roudehen, Iran \\ E-mail: mojtabamohammadi@gmail.com
}

\author{
Received: 04-09- 2014 \\ Accepted: 02-12- 2014 \\ Advance Access Published: December 2014 \\ Published: 01-05- 2015 \\ doi:10.7575/aiac.ijalel.v.4n.3p.53 \\ URL: http://dx.doi.org/10.7575/aiac.ijalel.v.4n.3p.53
}

\begin{abstract}
Investigating the efficiencies and deficiencies of reading strategies is one of the noticeable issues in the related theory and research in reading comprehension instruction. This study was to examine the impact of Directed Reading Thinking Activity (DRTA) and Guided Reading (GR) on reading comprehension. Sixty three Iranian students of grade one in Shahed high school in the city of Bojnourd took part in the study. They were assigned in three groups, one control and two experimental groups. The instruction lasted for ten weeks. This study utilized a pretest posttest control group in quantitative quasi- experimental design. The same reading comprehension test was administered as pre-test and posttest. The results were twofold: First, the instruction of learning strategies could foster reading comprehension skill. Second, while the explicit instruction of both strategies could improve the students' reading comprehension skill, Directed Reading Thinking Activity had a more significant positive effect than Guided Reading.
\end{abstract}

Keywords: reading strategy, explicit, directed reading thinking activity (DRTA), guided reading (GR)

\section{Introduction}

The development of reading comprehension in learners has long been investigated for two basic reasons: Literacy (reading to live) and academic achievement (reading to think). Reading comprehension is now the basic need of a citizen to live and to act successfully in his professional and academic contexts. It is even viewed to be the core language skill to build the development of all other language skills and subskills such as Listening, speaking, writing, vocabulary and grammar (Anderson, 2012). In addition, the twentieth and early twenty-first centuries have been the time of numerous migrations around the world and the use of world languages increased. Hence, in the modern linguistically diverse societies, the level of expectation for a person to function well is higher than those in the past local communities (Grabe, 2009).

\section{Review of the literature}

\subsection{Reading comprehension: An overview}

Reading comprehension has been looked differently during the ages. In 1950s, behavioral psychology explained reading in narrow terms of stimulus-response theory. Instruction was developed to practice the identified sub-skills. After that, in the 1970s, cognitive psychologists began looking at ways people solve problems. "Olshavsky (1976-77) was among the first to apply this idea to reading" (Vander Does, 2012, p. 14). He began a number of studies on reading as a cognitive problem-solving process. Finally, others conducted a kind of review of cognitive processing studies of reading comprehension which investigated categories of strategies used before, during, and after reading such as constructing a goal, predicting, and activating prior knowledge. These studies provided the field with a vision for teaching comprehension.

Before proceeding further, it seems necessary to define comprehension in a way that clearly specifies its key elements.The definition by Snow (2002) which is cited many times in different sources is "the process of simultaneously extracting and constructing meaning through interaction and involvement with written language" (as cited in Dougherty Stahl, 2003, p. 17; Bernhardt, 2011, p. 7; Marshall, 2006, p.14). Based on this definition, comprehension entails three elements: The reader, the text, and the activity. According to Snow (2002), the reader refers to all the capacities, abilities, knowledge, and experiences that a person brings to the act of reading. Text refers to any printed text or electronic text that is to be comprehended. And activity refers to the purposes, processes, and consequences associated with the act of reading. Then meaning is constructed as an interaction among these three elements, within a larger sociocultural context. 
Reading comprehension, according to Blachowicz and Ogle (2008), is a process demanding skills and strategies. A great deal of research has explored and supported the impact of learning/teaching reading strategies on accelerating second language learning (Blachowicz \& Ogle, 2008; Davis, 2010; Hong-Nam \& Leavell, 2007; Mohammadi, 2009; Salataci \& Akyel, 2002; Shang, 2010; Van Keer, 2004; Wright \& Brown, 2006; Yau, 2005). Good comprehenders know how to control reading, to construct meaning, and to monitor their reading by using reading strategies appropriately. Lots of strategies have been devised and revised so far. However, choosing the appropriate strategy depends on different factors like, the level of students, the kind of the text, students' culture and background knowledge, purpose of reading, etc.

McNamara (2007) mentioned three reasons to claim the necessity of reading comprehension strategies. First, many readers do not know exactly whether they are adequately comprehending the text. It is believed that acquisition of reading strategies help readers improve their comprehension calibration. Second, many readers have a misconception of comprehension. When they read a text, they settle for shallow levels of comprehension. These Shallow readers believe they have adequately comprehended a text if they can recognize the words and most of the sentences. However, "deep comprehension requires inferences, linking ideas coherently, scrutinizing the validity of claims with a critical stance, and sometimes understanding the motives of authors" (McNamara, 2007, p. 4). Third, deep comprehension of technical text is a difficult challenge for nearly all adults even skill readers. As a result acquisition of better strategies of reading comprehension is needed as a lifelong reading. And finally, Lems, Miller, and Soro (2010) put it in their words: "Reading comprehension requires the use of strategies before, during, and after reading" (p. 172).

\subsection{Reading Comprehension Strategies}

Reading comprehension strategies can be divided in two groups: single reading comprehension strategies and combining reading strategies.

2.2.1 Single Reading Comprehension Strategy: Different lists of reading comprehension strategies were identified by various scholars and organizations.Some reading strategies are repeated in each list showing the importance of them. Zimmermann and Hutchins (2003) identified following seven reading comprehension strategies (as cited in Moreillon, 2007): Activating or building background knowledge, Using sensory images, Questioning, Making predictions and inferences, Determining main ideas, Using fix-up options, and Synthesizing. Guthrie, Wigfield, and Perencevich (2004) identified the following as strong strategies which can assist elementary readers: Activating background knowledge, Questioning in reading, Searching for information, Summarizing during reading, Organizing graphically, and Structuring story.

2.2.2 Combining Reading Strategies: Some researchers have examined how reading strategies work together in strategy packages (Guthrie et al, 2004). It seems reasonable since good readers coordinate a set of strategies to comprehend a text (Reutzel, Smith, \& Fawson, 2005). Blachowicz and Ogle (2008) introduced two groups of reading strategies: reading strategies for informational texts which include: The KWL, Reciprocal teaching, External text features, Nonfiction book report, Text previewing, Tables of contents, Internal text structures, Text structure frames, I-Charts, Reciprocal teaching, Questioning the author, Levels of questions. Reading Strategies for Fiction Texts: Map literature circles, Bookmarks, Story problem solving, Story impressions, Sketch to stretch, Save the last word for me, Journal writing, Great books shared inquiry, Grand conversations, Book clubs, Literature circles, and Readers' workshop.

\subsection{Directed Reading Thinking Activity and Guided Reading}

Two single reading comprehension strategies the present study has dealt with are directed reading thinking activity (DRTA) and guided reading (GR).

The directed reading thinking activity (DRTA) was developed by Stauffer in 1969. The DRTA is a strategy that guides students in asking questions about a text, making predictions, and then reading to confirm or refute their predictions. In fact, DRTA provides the teacher an opportunity to guide students to think like good readers do by anticipating, predicting, and then confirming and modifying their ideas with the story. DRTA is mostly used with fiction, but it can be used successfully with nonfiction too. Blachowicz and Ogle (2008) believed that DRTA is one of the strongest ways which can help teachers engage students actively in the pieces of literature they are reading. Al Odwan (2012) mentioned other advantage "the directed reading thinking activity is a much stronger model for building independent readers and learners"(p.141).

Guided reading was first identified in 1969 as aids to mathematics comprehension by Richard Earl and Harold. Herber described the three-level guide in 1970. Richardson (1986) defined guided reading as: "A group of activities prepared in advance, designed to help the students organize information from the chapter and to suggest the use of applicable skills to the task" (as cited in Maxworthy, 1994, p. 137). Maxworthy (1994) cited two groups of guided reading developed by Smith in 1987: Interlocking Guided reading which works on the hierarchical relationship among three levels of comprehension: literal (the recognition of ideas directly stated in the text), interpretive or inferential (ideas implied by the author), and applied (ideas that have application beyond the text). Non-Interlocking Guided reading is the interactive guided reading to foster higher-level thinking. The guided reading questions were designed to promote students' active dialogue about text by beginning with students' personal knowledge and experience. This guided reading reflects the interactive definition of reading that is dynamic interactive process of constructing meaning by 
combining the reader's existing knowledge with the text information within the context of the reading situation. Simply put, reading is accomplished through interactive rather than sequential processes.

\subsection{Review of the Related Studies}

A number of studies have been carried out on the application of DRTA. Some of these studies used DRTA with other strategies as combined reading strategies while some others used it as a single reading comprehension strategy.

Al Odwan (2012) investigated the effect of the cooperative DRTA on English secondary stage students' reading comprehension in Jordan. The result revealed that using DRTA improved students' reading comprehension.

Nazari and Hashemi (2012) measured the effect of DRTA on students' referential and inferential English reading comprehension skills. Moreover, they compared the effect of collaborative versus individual thinking-activity. The result indicated that the cooperative DRTA improves their referential and inferential reading comprehension skills.

Similarly, El-Koumy (2006) investigated the effects of the DRTA on Egyptian first-year secondary stage EFL students' referential and inferential reading comprehension. The findings showed that there were statistically significant differences in both referential and inferential reading comprehension on the post-test in favor of the experimental group.

Almanza (1997) examined a study which compared the effectiveness of cooperative learning and the DRTA during reading stories. Findings indicated that the majority of children scored higher in the cooperative reading groups than their counterparts from the Directed Reading Thinking Activities groups.

In other study, Dougherty Stahl (2003) designed a study to explore the effects of three instructional methods, the DRTA, KWL, and picture walks (PW) on the reading comprehension and science content acquisition of novice readers. Results indicated that picture walk and DRTA yielded statistically significant effects on fluency as measured by a timed maze task. Analysis of Cued Recall indicated that the DRTA yielded statistically significant effects in reading comprehension and science content acquisition.

With an eye to the above literature, it is blatantly revealed that directed reading thinking activity (DRTA) and guided reading (GR) have not yet received a deserving attention. Moreover, further studies are required, as suggested by Oxford (2001), to investigate "degree of success of various forms of strategy instruction for EFL or ESL students" and "to teach strategies effectively in both linguistically diverse and linguistically homogeneous classrooms" (p. 172). This study, therefore, aimed at investigating the effect of two strategies (DRTA and GR) on reading comprehension of high school students in Iran.

The following research questions were raised in the present study:

1. Does the instruction of Directed Reading Thinking Activity (DRTA) have any significant effect on improving reading comprehension skill of the Iranian high school students?

2. Does the instruction of Guided Reading (GR) have any significant effect on improving reading comprehension skill of the Iranian high school students?

3. Is there any significant difference between the effect of DRTA and GR on reading comprehension skill of the Iranian high school students?

\section{Methodology}

\subsection{Participants}

The subjects of the study consisted of 78 boy students in grade one in Shahed high school in Bojnourd, Iran. Almost all of the students were 15 years old and they were in the second semester of the academic year 2012-2013 at the time of the study. At the beginning of the academic year, the school principal divided the grade one students (the subjects of this study) in three equal classes based on their GPA in the previous year. Therefore, the researcher randomly assigned these classes in three groups, two experimental groups and one control group. However, the Nelson proficiency as a test of homogeneity was administered to make sure of the homogeneity of these three groups in terms of level of proficiency.

\subsection{Research instruments}

To measure the students' reading comprehension as a pre-test and post-test, three passages from the book: Active skills for reading: Intro (Anderson, 2008) were chosen. The test consisted of fifteen multiple choice and essay-type items to assess the reading comprehension of subjects.

To ensure further validation of the test, three EFL teachers and two university professors were consulted, and their comments were taken into consideration. To ensure its reliability, the test was administered to a sample of thirty five students in another high school. The result showed the reliability of 0.87 .

The instructional materials for the study consisted of five lessons. They were reading parts of high school English book 1, lessons 5-9. Then, the subjects in experimental groups A and B received the instruction of DRTA and GR strategies respectively. The subjects in the control group had no explicit instruction of reading strategies along the course materials. 


\subsection{Procedures}

Before commencing the study, piloting was undertaken to check the reliability of pre-test reading comprehension. Therefore, 37 students in grade one in another high school sat for the pre-test. The reliability index was calculated to be 0.65 . After deleting two items, the reliability increased to 0.87 which was reasonable.

Before conducting the research, the approval of Shahed high school authorities was collected. As mentioned before, school principal assigned the students in grade one (the subjects of this study) to three equal classes based on their GPA in the previous year. However, in order to make sure that three classes were equal and homogenous, the researchers used Nelson language proficiency test. The test was administered to the participants who were about 78 boy students in grade one in all three classes. After analyzing the data, some students with extreme scores were crossed out from each class. Then, three homogeneous classes with the average of 21 students in each class were formed. The experimental and control groups were pre-tested in the last week of February 2013 to measure reading comprehension skill before conducting the experiment.

Training consisted of two days per week, each day about 60 minutes. The experiment was conducted from February 2013 till May 2013.This study is naturalistic in the sense that researcher as a teacher worked with students in his classrooms as he typically does.

\subsection{Design of the Study}

This study utilized a pretest-posttest control group in quantitative quasi-experimental design. Three classes in grade one were assigned to two experimental and one control groups. All groups were pre-tested to measure their reading comprehension before conducting the study. During the study, the first experimental group experienced the Directed Reading-Thinking Activities, the second experimental group, Guided Reading, and the control group worked with conventional method of teaching reading comprehension. After the treatments, three groups were post-tested to investigate any significant differences in their reading comprehension scores. Put it simply, the data collected through pretests and the posttests underwent the statistical procedures so that the researchers could demonstrate the differences between reading comprehension proficiency of three groups with DRTA, GR, and no-strategy instruction.

\section{Results}

As stated above, three classes were formed by the high school principal. However, to ensure the homogeneity of the participants in terms of general language proficiency, Nelson language proficiency test was administered to 78 participants. After the test, a few (15 students) were crossed out to have homogenous groups.

Three groups were pre-tested in order to confirm that they were homogeneous regarding reading comprehension skill.

Table 1 represents the descriptive statistics for pretests of all three groups.

Table 1. Descriptive Statistics for Reading Pretest of Three Groups

\begin{tabular}{lcccccccccc}
\hline & & & & & \multicolumn{5}{c}{$95 \%$ Confidence Interval } \\
& N & Mean & SD & Median & Std. & $\begin{array}{c}\text { for Mean } \\
\text { Error }\end{array}$ & $\begin{array}{c}\text { Lower } \\
\text { Bound }\end{array}$ & $\begin{array}{c}\text { Upper } \\
\text { Bound }\end{array}$ & Min. & Max. \\
& & & & & & & & & \\
\hline Control & 21 & 7.33 & 1.826 & 7.00 & $7^{\mathrm{a}}$ & .398 & 6.50 & 8.16 & 4 & 11 \\
\hline Guided & 22 & 7.77 & 2.137 & 8.00 & $8^{\mathrm{a}}$ & .456 & 6.83 & 8.72 & 4 & 12 \\
DRTA & 20 & 8.10 & 1.861 & 8.00 & 8 & .416 & 7.23 & 8.97 & 5 & 12 \\
\hline Total & 63 & 7.73 & 1.944 & 8.00 & 8 & .245 & 7.24 & 8.22 & 4 & 12 \\
\hline
\end{tabular}

a. Multiple modes exist. The smallest value is shown

The mean indices of reading pretests of the three groups were not far from each other implying that they were at the same level of reading comprehension.

In order to compare the mean score of the control, guided, and DRTA groups on reading posttest, the participants' performances on reading posttest in the three groups were summarized in Table 2 below. 
Table 2. Descriptive Statistics of the Three Groups on Posttest

\begin{tabular}{|c|c|c|c|c|c|c|c|c|c|c|}
\hline & \multirow{2}{*}{$\mathrm{N}$} & \multirow{2}{*}{ Mean } & \multirow[b]{2}{*}{ Median } & \multirow[b]{2}{*}{ Mode } & \multirow{2}{*}{ SD } & \multirow{2}{*}{ Std. Error } & \multicolumn{2}{|c|}{$\begin{array}{l}\text { 95\% Confidence Interva } \\
\text { for Mean }\end{array}$} & \multirow{2}{*}{ Min. } & \multirow{2}{*}{ Max. } \\
\hline & & & & & & & $\begin{array}{l}\text { Lower } \\
\text { Bound }\end{array}$ & $\begin{array}{l}\text { Upper } \\
\text { Bound }\end{array}$ & & \\
\hline Control & 21 & 8.62 & 9.00 & 9 & 1.910 & .417 & 7.75 & 9.49 & 5 & 12 \\
\hline Guided & 22 & 9.14 & 9.00 & 9 & 1.781 & .380 & 8.35 & 9.93 & 6 & 13 \\
\hline DRTA & 20 & 10.90 & 11.00 & 11 & 2.024 & .452 & 9.95 & 11.85 & 7 & 14 \\
\hline Total & 63 & 9.52 & 9.00 & 9 & 2.109 & .266 & 8.99 & 10.05 & 5 & 14 \\
\hline
\end{tabular}

A quick look at the Table 4.2 above shows that the mean indices of reading posttests of the three groups were far from each other even though the indices of standard deviation in all three groups were almost the same. A one-way between groups analysis of variance was conducted to explore the impact of three groups on reading comprehension. The results of ANOVA to compare the reading comprehension mean scores of the three groups on posttest are manifested in Table 3 .

Table 3. ANOVA for Comparing Control, Guided, and DRTA Groups on Reading Posttest

\begin{tabular}{llllll} 
& Sum of Squares & df & Mean Square & F & Sig. \\
\hline Between Groups & 58.371 & 2 & 29.185 & 8.057 & .001 \\
\hline Within Groups & 217.343 & 60 & 3.622 & & \\
\hline Total & 275.714 & 62 & & & \\
\hline
\end{tabular}

ANOVA detected a statistically significant difference at the $p<.05$ level on reading posttest scores for the three groups $\left(F_{(2,60)}=8.05, p=.001\right)$, in which $F$ ratio of 8.05 is greater than the $F$ critical of 3.15 , and the $p$ value of .001 is less than .05 , but ANOVA did not tell us the exact location of the difference. Hence, to test the hypotheses and show the exact location of these differences, the Scheffe Test was applied. The results of Scheffe Test are displayed in Table 4.

Table 4. Scheffe Test for Multiple Comparisons of Three Groups on Reading Posttest

\begin{tabular}{|c|c|c|c|c|c|c|}
\hline \multirow{2}{*}{ (I) Group } & \multirow{2}{*}{ (J) Group } & \multirow{2}{*}{$\begin{array}{l}\text { Mean Difference } \\
(\mathrm{I}-\mathrm{J})\end{array}$} & \multirow{2}{*}{ Std. Error } & \multirow{2}{*}{ Sig. } & \multicolumn{2}{|c|}{$\begin{array}{l}\text { 95\% Confidence Interval for } \\
\text { mean }\end{array}$} \\
\hline & & & & & Lower Bound & Upper Bound \\
\hline \multirow{2}{*}{ Control } & Guided & -.517 & .581 & .674 & -1.97 & .94 \\
\hline & DRTA & $-2.281^{*}$ & .595 & .001 & -3.77 & -.79 \\
\hline \multirow{2}{*}{ Guided } & Control & .517 & .581 & .674 & -.94 & 1.97 \\
\hline & DRTA & $-1.764^{*}$ & .588 & .015 & -3.24 & -.29 \\
\hline \multirow{2}{*}{ DRTA } & Control & $2.281^{*}$ & .595 & .001 & .79 & 3.77 \\
\hline & Guided & $1.764^{*}$ & .588 & .015 & .29 & 3.24 \\
\hline
\end{tabular}

*. The mean difference is significant at the 0.05 level.

H1. Scheffe test indicated that the mean score for DRTA group $(M=10.90, S D=2.02)$ was significantly different from control group $(M=8.62, S D=1.91)$, and guided group $(M=9.14, S D=1.78)$.

The mean score for DRTA group was significantly different from control group $(p=.001, p<\alpha)$ in which $p$ value is less than .05; accordingly, the first null hypothesis which predicted that instruction of Directed Reading Thinking Activity has no effect on improving reading comprehension skill of the Iranian high school students could be safely rejected, and it can be asserted that instruction of Directed Reading Thinking Activity has a significant effect on improving reading comprehension skill of the Iranian high school students. 
H2.Scheffe test also revealed that guided group $(M=9.14, S D=1.78)$ was not significantly different from control group $(M=8.62, S D=1.91)$ since the $p$ value for the difference between them was .67 , which is greater than .05 ; accordingly, the second null hypothesis which stated that the instruction of Guided Reading has no effect on improving reading comprehension skill of the Iranian high school students could not be rejected and it can be claimed that the instruction of Guided Reading has no significant effect on improving reading comprehension skill of the Iranian high school students.

H3. In addition, Scheffe test detected a significant difference between DRTA and guided group $(p=.01, p<\alpha)$ in which $p$ value was less than .05 . Thus, the third null hypothesis which stated that there is no significant difference between the effect of DRTA and Guided Reading onreading comprehension skill of the Iranian high school students was rejected. With high degree of confidence, we can claim that there is a significant difference between the effect of DRTA and Guided Reading on reading comprehension skill of the Iranian high school learners.

\section{Discussions and conclusion}

The findings of this study is consistent with the results of a number of studies which support the significant impact of DRTA on reading comprehension (Al Odwan, 2012; Dougherty Stahl, 2003; El-Koumy, 2006; Nazari \& Hashemi 2012). On the other hand, only one study has found the opposite results (Almanza, 1997).

Having reviewed a number of studies on the role of DRTA on reading comprehension, only one study, like the present study, compared DRTA with other strategies rather than investigating different ways of implementing single strategy DRTA on reading comprehension skill. Dougherty Stahl (2003) for example, studied the effects of three methods, DRTA, KWL and picture walks (PW). The results showed the significant effect of both DRTA and PW on reading comprehension.

Other studies mentioned here investigated different ways of implementing single strategy DRTA on reading comprehension skills. Al Odwan (2012) and Nazari and Hashemi (2012), for example, compared the cooperative verses individual reading thinking activity. Both reports were in favor of cooperative way of instruction. One other study (ElKoumy, 2006) investigated the effects of the DRTA on students' referential and inferential reading comprehension. DRTA was, like this study, effective both on referential and inferential reading comprehension.

In one study, the result was not in favor of DRTA (Almanza, 1997). He compared the effectiveness of cooperative learning and the Directed Reading Thinking Activity during reading stories. The difference in the results may be attributed to differences in the research methodologies, operationalization of DRTA, participants' levels of proficiency, text difficulty, and other factors. Furthermore, the experimental group with cooperative learning may have been enriched with communicative task to engage the learners in the story. This cooperative learning may assist subjects to outperform comparing the subjects with DRTA instruction.

This study showed that DRTA was more effective than not only the no-strategy group but also the Guided Reading one (other experimental group). One reason may be the nature of DRTA which entirely involves students during the reading process and helps them to be critical to their learning. Other reason may be related to the kind of the texts used in this study. These texts were the reading parts of grade one in high school. Almost all these texts in grade one are story passages and, according to Blachowicz and Ogle (2008), DRTA is one of the strategies which is effective with story and fiction text. On the other hand, Guided Reading strategy can be used with both information texts and fiction or story texts.

In view of the theoretical framework and empirical studies stated earlier in the literature section, Al Odwan, (2012) cited that there was significant improvement in the students' reading skills since the students began viewing the reading process as a meaningful experience rather than just rapidly going through reading material to get specific answers to evaluations. Furthermore, using Directed Reading Thinking Activity improves students' reading comprehension because these activities are rich with more interactive tasks and consequently provide students with new concepts, ideas, suggestions, styles of thinking.

The findings of this study generally suggest the importance of incorporating reading strategies in instruction of reading comprehension to lead students to greater learning opportunities and to make reading in second language an autonomous process. Furthermore emphasis should be given in helping the students develop the ability to use strategies effectively. The findings of this study confirm that if young students are taught reading strategies, they can become better readers. Also, explicit implementation of reading strategies can be beneficial to young learners.

The findings of this study specifically suggest that the DRTA strategy is an effective one for developing reading comprehension in the Iranian context. This strategy emphasizes the development of thinking skills and involves the students in processes to enhance learning. This strategy should be used for teaching reading comprehension from the outset of instruction. It should be noted that, success with the DRTA does not come immediately, but the effort should be made for any teacher who wants to develop thinking readers. The findings, however, are limited by the participants' level, the length of the study, and the operationalization of the dependent and independent variables of the study. 


\section{References}

Almanza, T. (1997). The effects of the D.R.T.A. and co-operative learning strategies on reading comprehension. Retrieved on Feb. 22, 2013 from http://www.eric.ed.gov/

Al Odwan, T. (2012). The effect of the directed reading thinking activity through cooperative learning on English secondary stage students' reading comprehension in Jordan. International Journal of Humanities and Social Science, 2(16). Retrieved on Feb. 10, 2013 from http://www.ijhssnet.com/journals/Vol_2_No_16_ Special_Issue_August_2012/15.pdf

Anderson, N. J. (2008). Active skills for reading: Intro. Canada: Thomson Heinle.

Anderson, N. L. (2012). Reading instruction. In A. Burns and J. C. Richards (Eds.), The Cambridge guide to pedagogy and practice in second language teaching (pp. 218-225). New York: Cambridge University Press.

Bernhardt, E. B. (2011). Understanding advanced second-language reading. New York: Routledge.

Blachowicz, C., \& Ogle, D. (2008). Reading comprehension strategies for independent learners. New York: The Guilford press.

Davis, D. S. (2010). A meta-analysis of comprehension strategy instruction for upper elementary and middle school students. Unpublished $\mathrm{PhD}$ dissertation, Vanderbilt University, USA.

Dougherty Stahl, C. A. (2003). The effect of three instructional methods on the reading comprehension and content acquisition of novice readers (Unpublished Master's thesis, University of Georgia, Athens, Georgia). Retrieved on March 25, 2013from http://athenaeum.libs.uga.edu/.../stahl_katherine_a_200305_edd.pdf

El-Koumy, A. (2006).The effects of the directed reading-thinking activity on EFL students' referential and inferential comprehension (Unpublished Master's thesis, University of Suez Canal University, Egypt). Retrieved on April 10, 2013 from http://www.eric.ed.gov

Grabe, W. (2009). Reading in a second language: Moving from theory to practice. Cambridge, UK: Cambridge University Press.

Guthrie, J. T., Wigfield, A., \& Perencevich, K. C. (2004). Motivating reading comprehension: Concept-oriented reading instruction. New Jersey: Lawrence Erlbaum Associates

Hong-Nam, K., \& Leavell, A. G. (2007). A comparative study of language learning strategy use in an EFL context: Monolingual Korean and bilingual Korean-Chinese university students. Asia Pacific Education Review, 8 (1), 71-88.

Lems, K., Miller, L. D., \& Soro, T. M. (2010). Teaching reading to English language learners: Insights from linguistics. New York: Guilford Publications, Inc.

Marshall, J. C. (2006). The effects of participation in literature circles on reading comprehension. (Unpublished Master's thesis, University of Miami, Coral Gables, Florida). Retrieved on Apr. 10, 2013 from http://scholarlyrepository.miami.edu/cgi/viewcontent.cgi?article=1049 \&context=oa_dissertations

Maxworthy, A. G. (1994). Do study guides improve text comprehension? Reading Horizons, 34(2). Retrieved on April 15, 2013 from scholarworks.wmich.edu/cgi/viewcontent.cgi?article. Reading

McNamara, D. S. (2007). Reading comprehension strategies: Theories, interventions, and technologies. Mahwah, New Jersey: Lawrence Erlbaum Associates.

Mohammadi, M. (2009). On the relationship between learning strategies and EFL learners' level of proficiency. Modern Thoughts in Education, 4(3), 103-116.

Moreillon, J. (2007). Collaborative strategies for teaching reading comprehension: Maximizing your impact. Chicago: American library association.

Nazari, M., \& Hashemi, M. R. (2012).Cooperative directed reading-thinking activity and referential-inferential reading comprehension skills. The Iranian EFL Journal, 8(5). Retrieved on Jan. 12, 2013 from http://www.Iranian-efljournal.com

Oxford, R. L. (2001). Language learning strategies. In R. Carter and D. Nunan (Eds.), The Cambridge guide to teaching English to speakers of other languages (pp. 166-172). New York: Cambridge University Press.

Reutzel, D. R., Smith, J. A., \&Fawson, P. C. (2005). An evaluation of two approaches for teaching reading comprehension strategies in the primary years using science information texts. Early Childhood Research Quarterly, 20, 276-305.

Salataci, R., \& Akyel, A. (2002). Possible effects of strategy instruction on L1 and L2 reading. Reading in a foreign language, 14 (1), 234- 255.

Shang, H. (2010). Reading strategy use, self-efficacy and EFL reading comprehension. Asian EFL Journal, 12 (2), 1842. 
Snow, C. (2002). Reading for understanding: Toward an $R$ \& D program in reading comprehension. Washington, D. C.: Rand Corporation.

Vander Does, S. (2012). Describing comprehension teachers' observations of students' reading comprehension. (Unpublished Master's thesis, University of Rhode Island). Retrieved on May 10, 2013 from http://digitalcommons.ric.edu/etd

Van Keer, H. (2004). Fostering reading comprehension in fifth grade by explicit instruction in reading strategies and peer tutoring. British Journal of Educational Psychology, 74, 37 - 70.

Wright, M., \& Brown, P. (2006). Reading in a modern foreign language: Exploring the potential benefits of reading strategy instruction. Language Learning Journal, 33, 22-33.

Yau, J. C. (2005). Two Mandarin readers in Taiwan: Characteristics of children with higher and lower reading proficiency levels. Journal of Research in Reading, 28(2), 108-123. 